\title{
Penilaian Daya Tampung Sungai Jangkok dan Sungai Ancar Terhadap Polutan Organik
}

\author{
Assessment of Jangkok and Ancar River Asimilative Capacity to \\ Organic Pollutant
}

\author{
DYAH MARGANINGRUM ${ }^{1}$, MUHAMMAD RAHMAN DJUWANSAH ${ }^{1}$, DAN ASEP MULYONO² \\ ${ }^{1}$ Pusat Penelitian Geoteknologi - Lembaga Ilmu Pengetahuan Indonesia \\ ${ }^{2}$ Unit Pelaksana Teknik Liwa - Lembaga Ilmu Pengetahuan Indonesia \\ dmarganingrum@yahoo.com
}

\begin{abstract}
This paper aims to asses the assimilative capacity of organic pollutant in Jangkok river and Ancar River. This methods used the oxygen sag of Streeter Phelps equation with data observation such as hidraulic river and organic polutants. The organic pollutant observed consist of dissolved oxygen (DO), Biological Oxygen Demand (BOD), and Chemical Oxygen Demand (COD). The results show that Jangkok River still had self purification in the segment observation. It was explained the maximum deficit oxygen of 1889 $\mathrm{kg} /$ day that had relating $B O D$ value because domestic wastewater adding in drainage channel. Whereas Ancar River shows the low assimilative capacity in spite of the maximum deficit oxygen is lower than Jangkok River. It is $1044 \mathrm{~kg} /$ day. There is indicating turbulence factor that can increase the reaeration rate caused the DO deficit in Ancar river. Turbulence occurred because there are stones which placed in river flow and dam. Therefore, to increase the river assimilative capacity of pollutant, we need do wastewater controlling and technology intervention.
\end{abstract}

Keywords: assimilative capacity, intervention technology, pollution controlling

\section{ABSTRAK}

Makalah ini bertujuan melakukan penilaian daya tampung sungai Jangkok dan Sungai Ancar terhadap polutan organik. Metode yang digunakan adalah persamaan Oxygen Sag Streeter Phelps dengan data pengukuran hidrolik sungai maupun data polutan kimia organik. Polutan organik yang diukur terdiri atas oksigen terlarut (DO), penggunaan oksigen secara biologis (BOD), dan penggunaan oksigen secara kimiawi (COD). Hasil analisis menunjukkan bahwa Sungai Jangkok masih memiliki kemampuan daya pulih secara alamiah pada segmen yang diukur dengan nilai DO defisit maksimum sebesar $1889 \mathrm{~kg} / \mathrm{hari}$. DO defisit tersebut terkait dengan tingginya nilai BOD pada titik pengamatan karena penambahan air buangan melalui saluran drainase. Sedangkan Sungai Ancar menunjukkan kondisi dimana daya pulihnya relatif lebih rendah meskipun DO defisit maksimumnya lebih kecil dari Sungai Jangkok, yaitu sebesar $1044 \mathrm{~kg} / \mathrm{hari}$. Ada inidkasi bahwa rendahnya DO defisit pada Sungai Ancar karena adanya faktor turbulensi yang dapat meningkatkan laju reaerasi. Turbulensi terjadi karena adanya bebatuan yang terletak di aliran sungai serta bendung. Oleh karena itu, guna meningkatkan daya tampung sungai terhadap polutan yang masuk, perlu melakukan dua usaha secara simultan yaitu pengendalian limbah yang masuk ke badan sungai serta intervensi teknologi.

Kata kunci: daya tampung, intervensi teknologi, pengendalian pencemaran

\section{PENDAHULUAN}

Undang-Undang Nomor 26 Tahun 2007 tentang Penataan Ruang mengamanahkan bahwa Kajian daya dukung lingkungan hidup menjadi persyaratan dalam pengembangan ruang suatu wilayah. Hal tersebut diperlukan untuk menjamin bahwa kebijakan, rencana, dan atau program (KRP) yang dijalankan bersifat sustain (keberlanjutan). Sifat sustain tersebut mengandung pengertian bahwa semua aspek dalam KRP telah dipertimbangkan berdasarkan hasil kajian daya dukung lingkungan wilayah setempat.

Teriminologi daya dukung (carrying capacity) menurut Undang-Undang Nomor 32 Tahun 2009 terdiri atas kapasitas penyediaan sumberdaya alam (supportive capacity) dan kapasitas daya tampung limbah (asimilative capacity). 
Makalah ini bertujuan dan membatasi pembahasan dalam hal kajian kapasitas daya tampung limbah Sungai Jangkok dan Sungai Ancar. Posisi kedua sungai tersebut cukup strategis karena melintasi wilayah Kota Mataram sebagai Ibu Kota Provinsi Nusa Tenggara Barat. Sungai Jangkok sendiri merupakan sungai terbesar di Mataram yang melintasi tiga wilayah kabupaten, yaitu Kabupaten Lombok Utara, Lombok Barat, dan Lombok Tengah. Selain itu, Sungai Jangkok maupun Sungai Ancar menjadi sumber air baku untuk memenuhi kebutuhan domestik, pertanian, dan industri. Di lain pihak kedua sungai tersebut juga menjadi tempat pembuangan limbah rumah tangga dan industri $^{(1,2,3,4)}$. Mengingat pentingnya kedua sungai tersebut bagi masa depan Kota Mataram, maka mengetahui status daya tampung limbah kedua sungai tersebut sangat diperlukan. Informasi status daya tampung cukup penting untuk mengendalikan pembuangan limbah dan mengantispasi kondisi septik dari kedua sungai tersebut apabila beban limbah yang masuk sudah berada diatas ambang baku kedua sungai untuk melakukan pemurnian secara alamiah.

Secara kontekstual, pemurnian secara alamiah (natural self purification) didefinisikan sebagai suatu proses kompleks yang melibatkan proses fisik, kimia, dan biologis yang terjadi secara simultan, yang menggambarkan kemampuan sebuah sungai untuk merecovery status alamiahnya pada jarak tertentu $(5,6)$. Mekanisme yang terlibat dalam proses self purification antara lain pengenceran (dilution), pengendapan (sedimentation), reaerasi, adsorpsi, absorpsi, rekasi kimia, dan reaksi biologis yang dapat dievaluasi secara matematis. Model kualitas air ini akan cukup penting sebagai alat (tool) untuk mengetahui daya tampung sungai dan dalam jangka panjang dapat digunakan untuk mengembangkan perencanaan serta pengelolaan yang terukur terhadap sumberdaya air di sebuah Daerah Aliran Sungai (DAS) $)^{(7)}$.

Mengingat pentingnya mengetahui status daya tampung sungai, maka beberapa penelitian telah dilakukan untuk mengembangkan model-model matematis guna mengukur tingkat pencemaran sungai $(7,8,9,10,11,12)$. Model-model tersebut umumnya dibangun berdasarkan model dasar yang dikembangkan oleh Streeter Phelps yang awalnya diaplikasikan di Sungai Ohio pada tahun 2014 yang dikenal sebagai persamaan Oxygen Sag Streeter Phelps ${ }^{(5)}$. Pada hakikatnya, persamaan tersebut adalah mengukur kadar oksigen di dalam sungai dari mulai titik limbah masuk ke dalam sungai hingga jarak tertentu dimana limbah tersebut kemudian didekomposisi.

Pemerintah Indonesia menganggap studi daya tampung sumber air merupakan salah satu hal yang krusial, mengingat banyaknya sungaisungai di tanah air telah tercemar limbah. Oleh karena itu sejak tahun 2003, Pemerintah RI dalam Peraturan Pemerintah Nomor 82 Tahun 2001 tentang Pengelolaan Kualitas Air dan Pengendalian Pencemaran Air mengeluarkan pedoman penetapan data tampung beban pencemaran air pada sumber air dengan Metoda Neraca Massa, Metoda Streeter-Phelps, dan metode QUAL2E. Ketiga metode tersebut merupakan metode satu dimensi ${ }^{(12)}$. Metode neraca massa relatif sangat mudah karena hanya diperlukan data konsentrasi parameter polutan dan debit sungai. Paramater polutan yang diuji pun bisa bersifat konservatif maupun non konservatif. Polutan konservatif adalah polutan yang tidak mengalami perubahan konsentrasi terhadap waktu, sebaliknya polutan non konservatif, berubah terhadap waktu ${ }^{(13,14)}$. Sedangkan metode QUAL2E relatif lebih rumit dibandingkan kedua metode lainnya karena memerlukan bantuan perangkat komputer beserta software-nya untuk melakukan simulasi. Dengan pertimbangan-pertimbangan tersebut diatas, maka makalah ini akan menyajikan hasil kajian daya tampung sungai menggunakan metode Streeter-Phelps (Oxygen Sag). Metode ini dipilih untuk menguji kesehatan sungai karena diaplikasikan khusus untuk kontaminan yang non konservatif, dimana kehadiran oksigen diperlukan oleh ekosistem sungai untuk melakukan perombakan polutan secara biologis. Oleh karena itu, diperlukan data pengukuran oksigen terlarut. Selain itu, metode ini relatif lebih mudah dibandingkan metode QUAL2E sehingga Pemerintah Daerah setempat dapat melakukan replikasi secara lebih mudah tanpa dibebani kerumitan dalam hal teknologi komputerisasi.

\section{BAHAN DAN METODE}

Penelitian ini dilakukan di MataramLombok-Nusa Tenggara Barat. Gambar 1 adalah peta lokasi penelitian yang menunjukkan tempat pengambilan sampel air sungai di sekitar kota Mataram-Lombok, Nusa Tenggara Barat. Pengambilan sampel dibagi menjadi dua segmen. Segmen pertama adalah Sungai Jongkok dan segmen kedua adalah Sungai Ancar. Pada segmen pertama terdiri atas tiga titik sampling $(5,5 / 6$, dan 6$)$. Sedangkan pada segmen kedua terdapat 8 titik sampling $(15,14$, $13,12,11,10,9$, dan 8). 


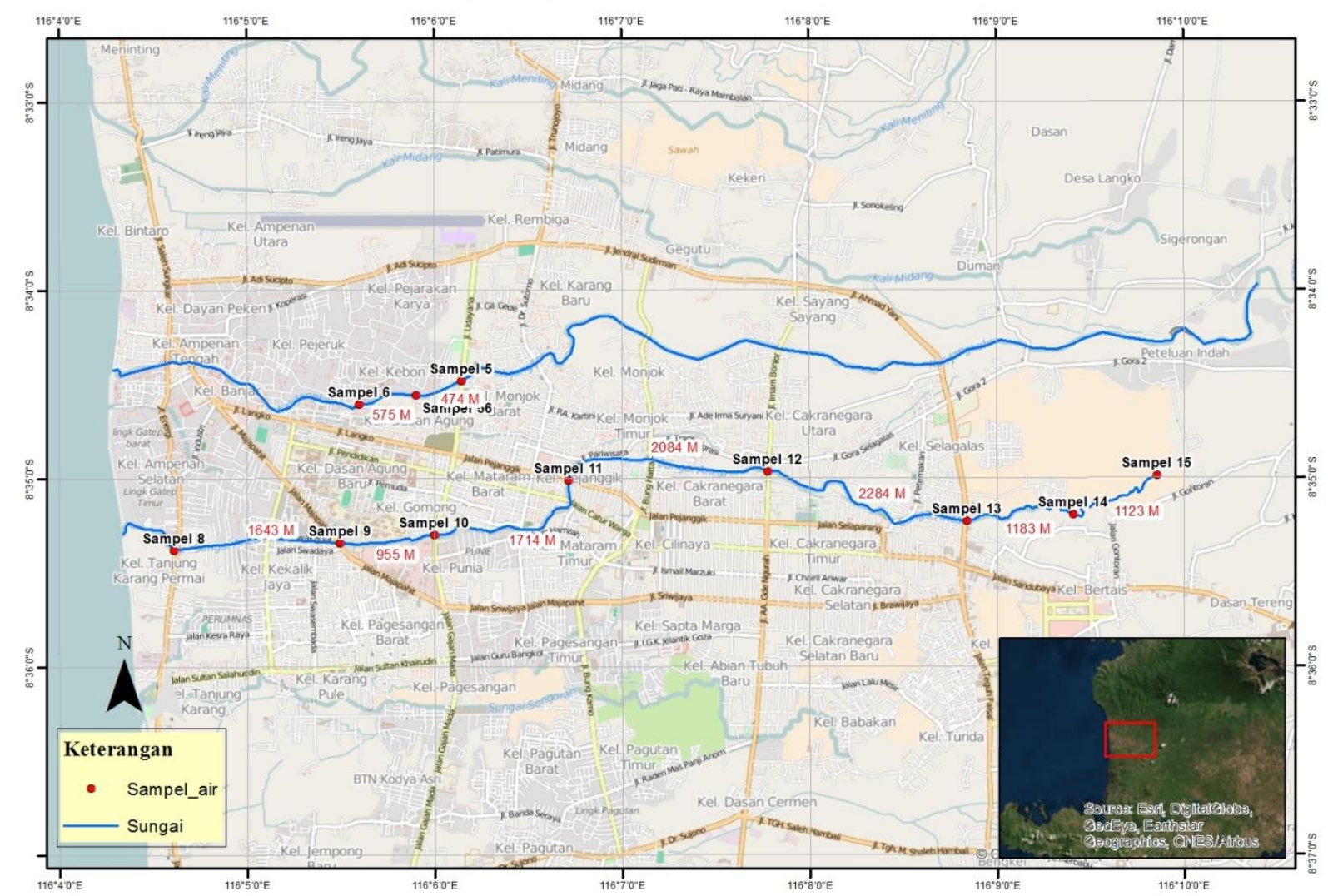

Gambar 1. Lokasi pengambilan sampel air sungai di Kota Mataram-Lombok

Koordinat lokasi sampling ditampilkan pada Tabel 1. Masing-masing titik sampling di kedua segmen sungai tersebut menunjukkan arah dari hulu ke hilir sungai. Setiap serial titik sampling, baik untuk Sungai Jangkok maupun Sungai Ancar, dilakukan dalam hari yang sama. Hal ini diperlukan untuk mengetahui bagaimana dinamika sungai pada waktu (t-hari) yang sama. Metodologi dalam penelitian dibagi kedalam metode pengambilan data dan metode analisa data.

\subsection{Metode Pengambilan Data}

Metode pengambilan data terdiri atas data kimia air sungai dan data hidrolika sungai. Data kimia air terdiri atas oksigen terlarut (DO), penggunaan oksigen secara biologis (BOD), dan penggunaan oksigen secara kimiawi (COD). Untuk DO dan BOD dilakukan dengan metode iodometer menggunakan botol winkler. Sedangkan untuk COD menggunakan metode closed reflux.

Tabel 1. Lokasi Pengambilan sampel

\begin{tabular}{c|c|c|c|c}
\hline \multirow{2}{*}{ Titik } & \multirow{2}{*}{ Tanggal pengukuran } & \multirow{2}{*}{ Nama Sungai } & \multicolumn{2}{|c}{ Lokasi } \\
\cline { 4 - 5 } & & & $\mathbf{X}$ & $\mathbf{Y}$ \\
\hline L-5 & 11 Mei 2016 & Sungai Jangko & $-8^{0} 34^{\prime} 29,54^{\prime \prime}$ & $116^{0} 06^{\prime} 09,31^{\prime \prime}$ \\
\hline L-5/6 & 11 Mei 2016 & Sungai Jangko & $-8^{0} 34^{\prime} 34,58^{\prime \prime}$ & $116^{0} 05^{\prime} 52,44^{\prime \prime}$ \\
\hline L-6 & 11 Mei 2016 & Sungai Jangko & $-8^{0} 34^{\prime} 35,21^{\prime \prime}$ & $116^{0} 05^{\prime} 54,83^{\prime \prime}$ \\
\hline L-15 & 12 Mei 2016 & Sungai Ancar & $-8^{0} 34^{\prime} 59,22^{\prime \prime}$ & $116^{0} 09^{\prime} 54,31^{\prime \prime}$ \\
\hline L-14 & 12 Mei 2016 & Sungai Ancar & $-8^{0} 35^{\prime} 10,42^{\prime \prime}$ & $116^{0} 09^{\prime} 20,33^{\prime \prime}$ \\
\hline L-13 & 12 Mei 2016 & Sungai Ancar & $-8^{0} 35^{\prime} 15,95^{\prime \prime}$ & $116^{0} 08^{\prime} 49,93^{\prime \prime}$ \\
\hline L-12 & 12 Mei 2016 & Sungai Ancar & $-8^{0} 34^{\prime} 58,74^{\prime \prime}$ & $116^{0} 07^{\prime} 47,14^{\prime \prime}$ \\
\hline L-11 & 12 Mei 2016 & Sungai Ancar & $-8^{0} 35^{\prime} 01,38^{\prime \prime}$ & $116^{0} 06^{\prime} 43,14^{\prime \prime}$ \\
\hline L-10 & 12 Mei 2016 & Sungai Ancar & $-8^{0} 35^{\prime} 19,91^{\prime \prime}$ & $116^{0} 06^{\prime} 00,27^{\prime \prime}$ \\
\hline L-9 & 12 Mei 2016 & Sungai Ancar & $-8^{0} 35^{\prime} 21,66^{\prime \prime}$ & $116^{0} 05^{\prime} 29,75^{\prime \prime}$ \\
\hline L-8 & 12 Mei 2016 & Sungai Ancar & $-8^{0} 35^{\prime} 22,98^{\prime \prime}$ & $116^{0} 04^{\prime} 37,16^{\prime \prime}$ \\
\hline
\end{tabular}


Sedangkan data hidrolika sungai diperlukan untuk mendapatkan data debit sungai. Untuk mendapatkan data debit riil pada saat pengambilan sampel, dua hal yang dilakukan adalah pengukuran luas penampang sungai dan kecepatan sungai. Untuk mendapatkan data luas penampang sungai, yang diukur adalah lebar dan kedalaman rata-rata sungai disekitar lokasi pengambilan sampel air. Perhitungan luas penampang $(A)$ ditentukan dengan persamaan di bawah ini:

$$
A=L \times H \text {. }
$$

Di mana:

$A=$ luas penampang sungai $\left(\mathrm{m}^{2}\right)$
$\mathrm{L}=$ lebar rata-rata sungai $(\mathrm{m})$
$\mathrm{H}=$ kedalaman rata-rata sungai $(\mathrm{m})$

Variabel kedua yang perlu ditentukan adalah kecepatan sungai. Perhitungan kecepatan sungai (v) ditentukan di bawah ini :

$$
v=P / t
$$

Di mana:

$$
\begin{aligned}
& \mathrm{v}=\text { kecepatan aliran }(\mathrm{m} / \text { detik) } \\
& \mathrm{P}=\text { panjang lintasan uji }(\mathrm{m}) \\
& \mathrm{t}=\text { waktu rata-rata (detik) }
\end{aligned}
$$

Setelah variabel luas penampang sungai dan kecepatan ditentukan, maka langkah selanjutnya adalah menghitung debit rata-rata pada saat sampel air sungai diambil. Perhitungan debit dilakukan dengan persamaan dibawah ini:

$$
Q=A \times \vee
$$

Dimana:

$Q=$ debit aliran sungai ( $\mathrm{m}^{3} /$ detik)

$\mathrm{V}=$ kecepatan aliran ( $\mathrm{m} /$ detik)

$A=$ luas penampang sungai $\left(\mathrm{m}^{2}\right)$

\subsection{Metode Perhitungan Daya Tampung Sungai}

Metode pendekatan perhitungan daya tampung sungai menggunakan model oxygen sag sebagaiman telah dijelaskan dalam pendahuluan. Model ini terdiri atas beberapa persamaan diferensial yang menggambarkan proses de-oxigenasi dan re-oxigenasi sebagai fungsi dari waktu dan jarak (yang berkaitan dengan kecepatan sungai), dengan asumsi bahwa keseimbangan oksigen terjadi dalam sistem aliran sungai yang terdistribusi secara merata $^{(7,15)}$.

Kesimbangan DO di dalam sungai setelah menerima limbah dapat diformulasikan dengan model oxygen sag menggunakan persamaan Streeter Phelps sebagai berikut ${ }^{(5)}$ :

$D_{\mathrm{r}}=\frac{k_{1} 2 a}{k_{2}-k_{1}}\left(10^{-k_{1} t}-10^{-k_{2} t}\right)+D a \times 10^{-k_{2} t}$.

Di mana:

Dt $=$ DO defisit di downstream $(\mathrm{mg} / \mathrm{L}$ atau pound/hari)

$\mathrm{La}=\mathrm{BOD}$ ultimate, nilai ini dapat ditentukan dari nilai BOD yang diukur pada temperatur $20^{\circ} \mathrm{C}$ selama 5 hari $\left(\mathrm{BOD}^{5}{ }_{20}\right), \mathrm{mg} / \mathrm{L}$ atau pound/hari. Menurut Lee dan Lin (2000) dibawah laju deoksigenasi normal, maka La sama dengan nilai $\mathrm{BOD}^{5}{ }_{20}$ hasil pengukuran dikalikan faktor 1,46 dalam satuan pound/hari ${ }^{(7)}$.

$\mathrm{k} 1=$ koefisien deoksigenasi berbasis nilai 10 $\left(\right.$ hari $^{-1}$ )

$\mathrm{k} 2=$ koefisien reoksigenasi berbasis nilai 10 $\left(\right.$ hari $^{-1}$ )

$\mathrm{Da}=$ nilai inisial defisit oksigen $(\mathrm{DO}$ jenuh dikurangi DO pengukuran), $\mathrm{mg} / \mathrm{L}$ atau pound/hari

$\mathrm{t}$ = waktu yang digunakan atau ditempuh dari up ke downstream. Nilai ini dapat ditentukan dari rasio antara jarak tempuh dari up ke down stream (s dalam mill) dan kecepatan aliran sungai $(v$, mill per jam) dimana kita melakukan pengambilan sampel air (hari), $\Delta \mathrm{t}=\mathrm{s} / \mathrm{v}$

Dengan melakukan modifikasi persamaan diatas $^{(5)}$, laju deoksigenasi (kd atau k1) dapat ditentukan dari persamaan dasar dalam menentukan BOD ultimate (La) pada dua titik tinjauan. Kemudian dengan cara logaritmik dari variabel La maka nilai kd dan k2 (koefisien deoksigenasi) dapat diketahui.

\section{HASIL DAN PEMBAHASAN}

\subsection{Analisis Variabel Fisik Hidrolik}

Tabel 2 adalah hasil pengukukuran dan perhitungan variabel fisik hidrolik Sungai Jangkok dan Sungai Ancar, yang masingmasing terdiri atas luas penampang sungai, kecepatan aliran sungai, dan debit sungai. 
Tabel 2. Hasil pengukuran dan perhitungan variabel fisik hidrolik

\begin{tabular}{|c|c|c|c|c|c|c|c|c|c|c|c|c|}
\hline \multirow{2}{*}{ Titik } & \multirow{2}{*}{$\begin{array}{c}\text { Lebar } \\
\text { (L) }\end{array}$} & \multicolumn{4}{|c|}{ Kedalaman $(\mathrm{H}), \mathrm{m}$} & \multirow{2}{*}{$\begin{array}{c}\text { Luas } \\
\begin{array}{c}\text { Penampang } \\
(\mathrm{A})\end{array} \\
\left(\mathrm{m}^{2}\right) \\
\end{array}$} & \multirow{2}{*}{$\begin{array}{c}\begin{array}{c}\text { Panjang } \\
\text { lintasan } \\
\text { (L) }\end{array} \\
\text { (m) }\end{array}$} & \multicolumn{4}{|c|}{ Kecepatan (v), m/detik } & \multirow{2}{*}{$\begin{array}{c}\text { Debit } \\
\text { Aliran (Q) } \\
\mathbf{m}^{3} / \text { detik }\end{array}$} \\
\hline & & $\mathrm{H} 1$ & $\mathrm{H} 2$ & H3 & $\begin{array}{c}\text { Rata- } \\
\text { rata }\end{array}$ & & & v1 & v2 & v3 & $\begin{array}{l}\text { Rata- } \\
\text { rata }\end{array}$ & \\
\hline \multicolumn{13}{|c|}{ Sungai Jangkok: } \\
\hline$L-5$ & 9,1 & 1,35 & 1,45 & 1,35 & 1,38 & 12,59 & 12 & 22 & 27 & 29 & 26,00 & 5,81 \\
\hline $\mathrm{L}-5 / 6$ & 15 & 0,75 & 0,85 & 0,95 & 0,85 & 12,75 & 10 & 13 & 14 & 15 & 14,00 & 9,11 \\
\hline $\mathrm{L}-6$ & 20 & 0,2 & 0,25 & 0,2 & 0,22 & 4,33 & 10 & 17 & 15 & 16 & 16,00 & 2,71 \\
\hline \multicolumn{13}{|c|}{ Sungai Ancar: } \\
\hline $\mathrm{L}-15$ & 4,2 & 0,25 & 0,3 & 0,25 & 0,27 & 1,12 & 10 & 8 & 9 & 6 & 7,67 & 1,46 \\
\hline $\mathrm{L}-14$ & 5 & 0,15 & 0,25 & 0,15 & 0,18 & 0,92 & 10 & 11 & 11 & 11 & 11,00 & 0,83 \\
\hline $\mathrm{L}-13$ & 10 & 0,15 & 0,35 & 0,15 & 0,22 & 2,17 & 10 & 11 & 11 & 12 & 11,33 & 1,91 \\
\hline $\mathrm{L}-12$ & 10 & 0,15 & 0,35 & 0,2 & 0,23 & 2,33 & 9 & 6 & 7 & 7 & 6,67 & 3,15 \\
\hline $\mathrm{L}-11$ & 10 & 0,45 & 0,5 & 0,45 & 0,47 & 4,67 & 10 & 13 & 11 & 11 & 11,67 & 4,00 \\
\hline $\mathrm{L}-10$ & 12 & 0,25 & 0,4 & 0,25 & 0,30 & 3,60 & 10 & 18 & 20 & 20 & 19,33 & 1,86 \\
\hline L-9 & 13,8 & 0,7 & 0,7 & 0,7 & 0,70 & 9,66 & 10 & 39 & 40 & 40 & 39,67 & 2,44 \\
\hline $\mathrm{L}-8$ & 9 & 0,4 & 0,45 & 0,4 & 0,42 & 3,75 & 10 & 7 & 8 & 8 & 7,67 & 4,89 \\
\hline
\end{tabular}

Sumber: Hasil pengukuran dan perhitungan yang dilakukan pada Mei 2016

Hasil pengukuran debit di segmen Sungai Jangkok dan Sungai Ancar secara grafis dapat dilihat pada Gambar 2. Terlihat bahwa debit di kedua sungai bersifat fluktuatif. Ini menunjukkan bahwa data debit bersifat acak dan stokastik yang terkait dengan dinamika aktivitas penduduk serta iklim atau cuaca yang terjadi di lokasi penelitian. Oleh karena itu, pendekatan statistik dapat dilakukan untuk mengetahui sensibilitas atau kecenderungan data debit sungai di suatu kawasan sesuai dengan jumlah data dan aturan yang berlaku ${ }^{(16,17)}$.

\subsection{Analisis Daya Tampung}

Tabel 3 dan Tabel 4 menunjukkan hasil pengukuran dan perhitungan, masing masing dari data segmen Sungai Jangkok dan segmen Sungai Ancar. Satuan BOD dan DO yang semula $\mathrm{mg} / \mathrm{L}$ dikonversi menjadi pound/hari, masing-masing sebagai rata-rata $B O D(L)$ dan rata-rata $D O$ defisit (D) untuk mempermudah perhitungan sesuai persamaan (i) dan menunjukkan massa dari polutan (Tabel 3 dan
Tabel 4). Konversi ini diperlukan karena persamaan Streeter Phelps merupakan pengembangan dari metode Keseimbangan Massa untuk menghilangkan pengaruh dari fluktuasi debit dalam aliran sungai selama proses perhitungan dilakukan ${ }^{(5)}$.

Gambar 3 dan Gambar 4 adalah profil DO defisit masing-masing di segmen Sungai Jangkok dan Sungai Ancar yang merupakan gambaran dari kondisi daya tampung Sungai Jangkok saat itu terhadap polutan organik yang ada di dalamnya. DO defisit $(\mathrm{mg} / \mathrm{L})$ yang terlihat sebagai ordinat pada Gambar 3 dan Gambar 5 menunjukkan nilai Dt yaitu DO defisit di downstream untuk satu step perhitungan (dari titik 1 ke titik 2). Selanjutnya nilai $\mathrm{Dt} d \mathrm{di}$ downstream setiap step digabungkan ke step berikutnya sehinga terbentuk profil DO defisit, baik untuk segmen Sungai Jangkok maupun segmen Sungai Ancar seperti yang ditunjukkan pada Gambar 3 dan Gambar 5.

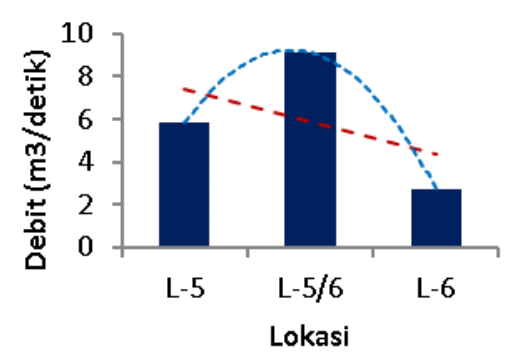

(a) Segmen Sungai Jangkok

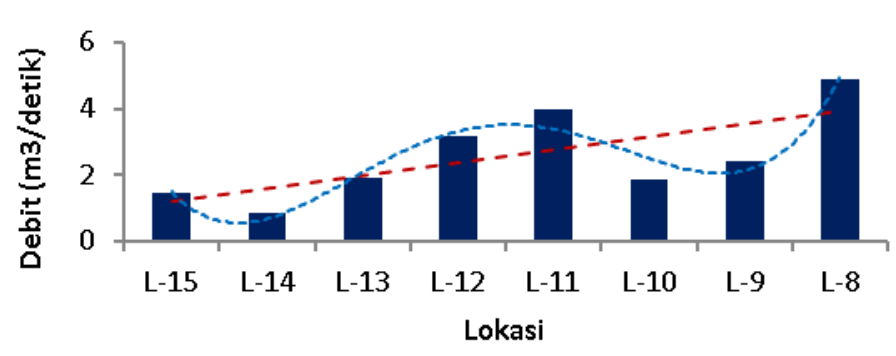

(b) Segmen Sungai Ancar

Gambar 2. Hasil pengukuran debit di dua segmen sungai di sekitar Kota Mataram 
Tabel 3. Hasil pengukuran dan perhitungan daya tampung Sungai Jangkok

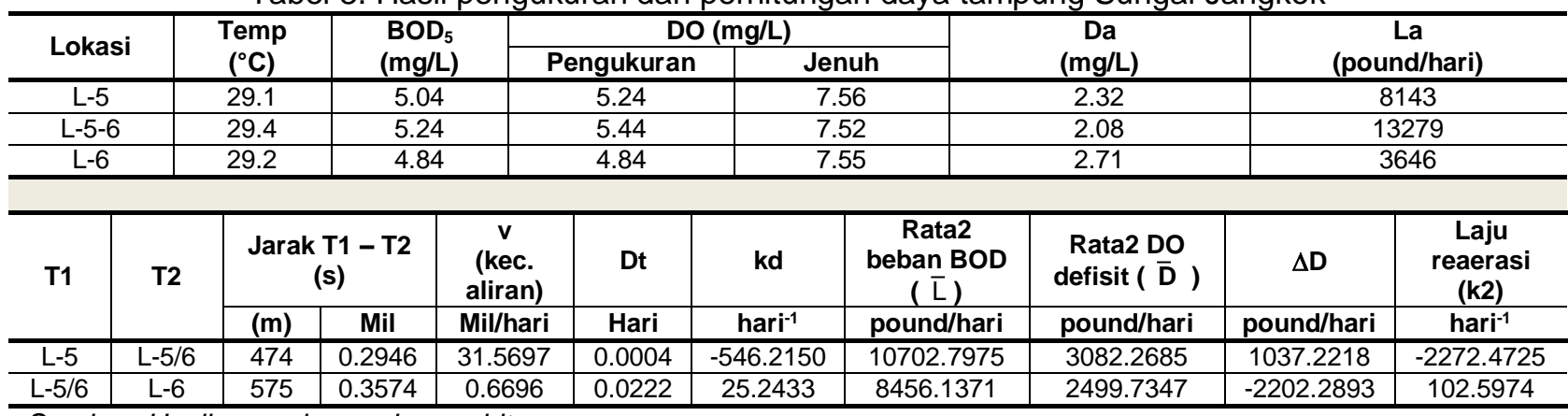

Sumber: Hasil pengukuran dan perhitungan

Tabel 4. Hasil pengukuran dan perhitungan daya tampung Sungai Ancar

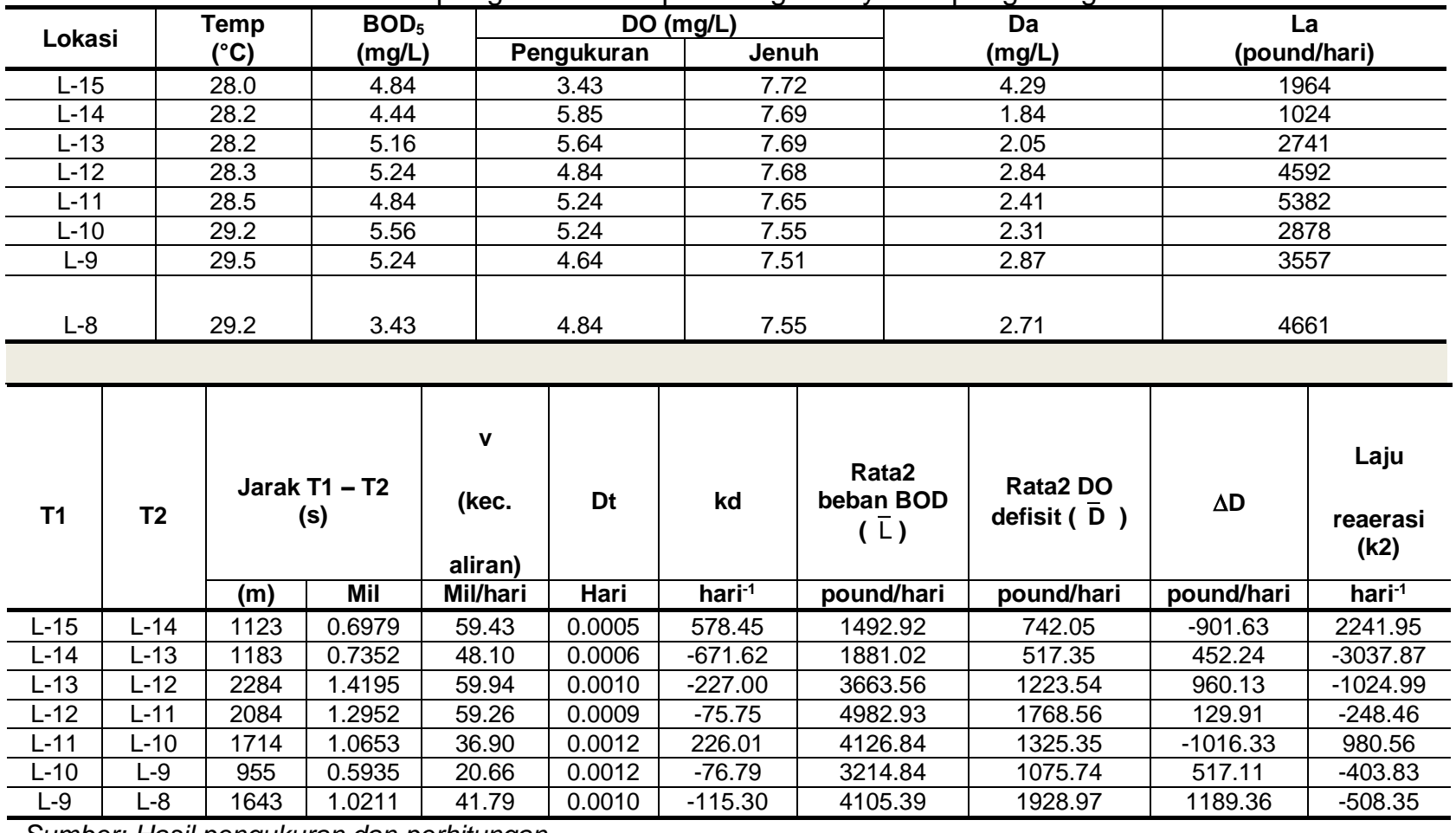

Sumber: Hasil pengukuran dan perhitungan

Gambar 3 adalah profil DO defisit di segmen Sungai Jangkok. Pada Gambar 3 terlihat bahwa segmen Sungai Jangkok yang dipilih pada studi ini memiliki kemampuan untuk melakukan perombakan polutan organik secara alami. Kenaikan DO terjadi setelah titik $5 / 6$. Ada indikasi bahwa pengaruh besarnya debit air sungai cukup besar pada segmen Sungai Jangkok dalam mempengaruhi proses pemulihan $^{(18)}$. Dapat diperhatikan bahwa profil debit sungai (Gambar 2a) berbanding terbalik dengan profil yang ditunjukkan pada Gambar 3. Selain debit, kadar atau konsentrasi BOD adalah hal utama yang mempengaruhi kapasitas asimilatif( ${ }^{(19)}$. Ini ditunjukkan pada profil BOD ultimate di segmen Sungai Jangkok (Gambar 4).

Kondisi yang sama juga ditunjukkan dari hasil analisis di Sungai Ancar. Gambar 5 dan Gambar 6 masing-masing menunjukkan profil DO defisit dan profil BOD ultimate di segmen
Sungai Ancar. Faktor debit dan konsentrasi BOD menjadi indikasi bagaimana kemampuan atau kapasitas asimilatif sungai. Semakin kecil debit dan semakin tinggi konsentrasi BOD maka semakin rendah kapasitas asimilatif sungai dan sebaliknya. Oleh karena itu peningkatan daya tampung sebuah sungai dapat dilakukan melalui pengenceran atau menurunkan konsentrasi BOD dari efluent yang dibuang ke dalam sungai dengan terlebih dahulu melakukan pengolahan (treatment)(20). Pernyataan ini juga diperkuat dengan hasil analisis yang dapat dilihat pada Gambar 5, khususnya terlihat dengan jelas di segmen T13-T12, T12-T11, dan T11-T10 Sungai Ancar yang menggambarkan kondisi riil aktivitas yang terjadi di lapangan (Gambar 7).

Gambar 7 menunjukkan lokasi pengambilan sampel air di segmen Sungai Ancar. Profil DO defisit maupun profil BOD ultimate di segmen T-13 s.d. T-10 merupakan 
realisasi dari kondisi riil yang ada di lapangan. Pada titik T-13 terdapat turbulensi air walaupun kecil. Turbulensi terjadi karena adanya tumpukan batu yang berada di tengah sungai. Pada titik T-12 terdapat inputan aliran yang berasal dari saluran drainase, dan disekitar lokasi sampling juga terdapat masyarakat yang melakukan aktivitas MCK. Pada titik T-11 terdapat pembuangan langsung dari limbah rumah tangga. Pada titik $\mathrm{T}-10$ terdapat bendung air yang menyebabkan terjadinya turbulensi.

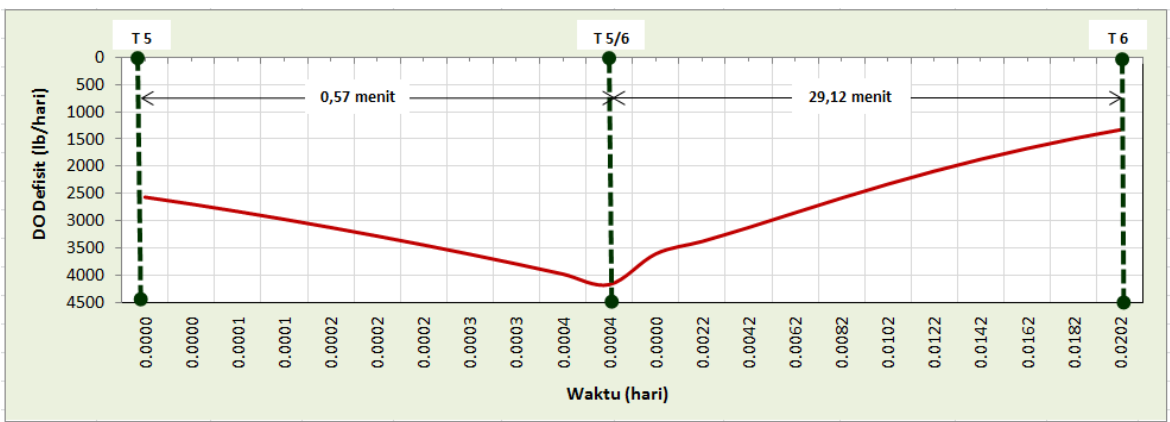

Gambar 3. Profil DO defisit terhadap waktu di segmen Sungai Jangkok

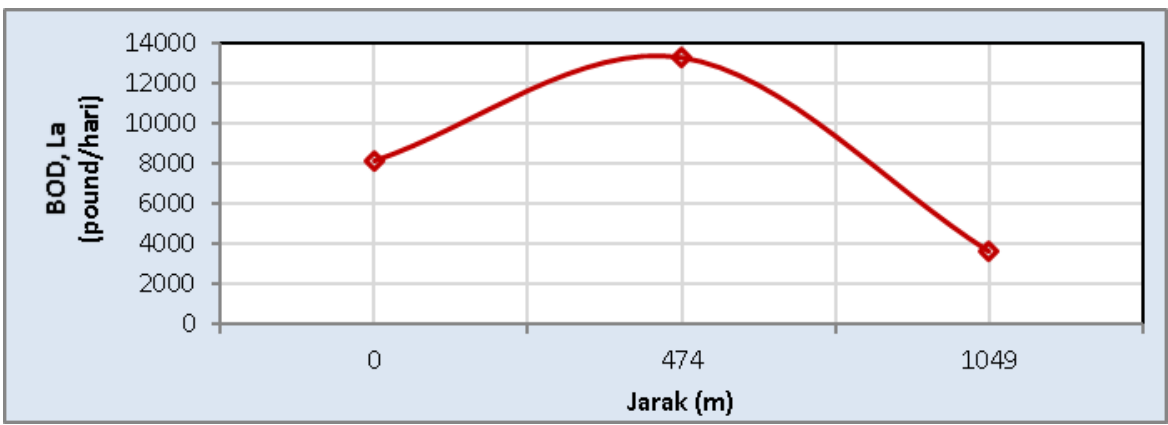

Gambar 4. Profil BOD ultimate terhadap jarak di segmen Sungai Jangkok

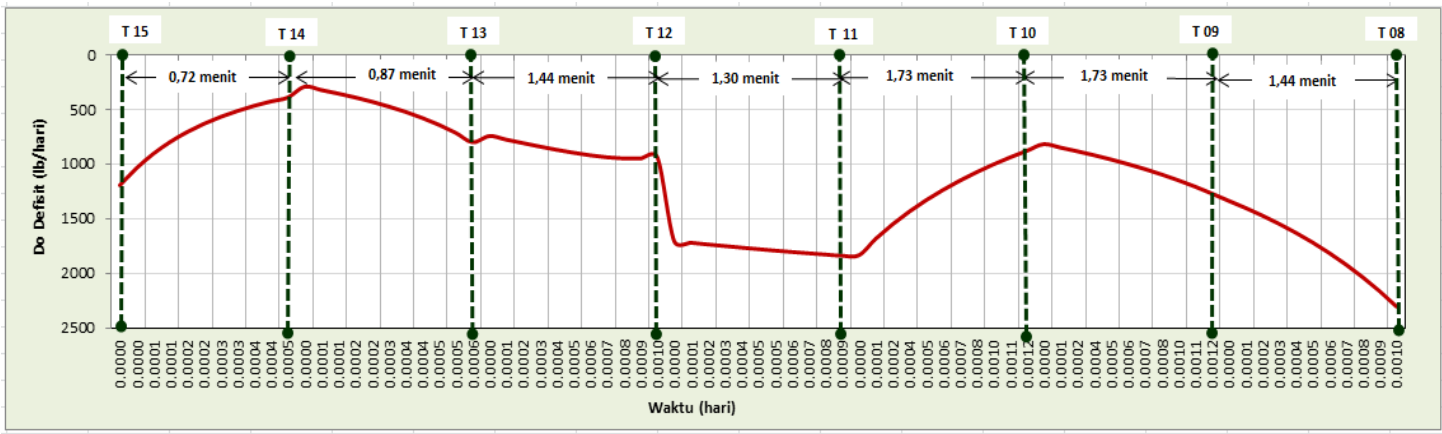

Gambar 5. Profil DO defisit di segmen Sungai Ancar

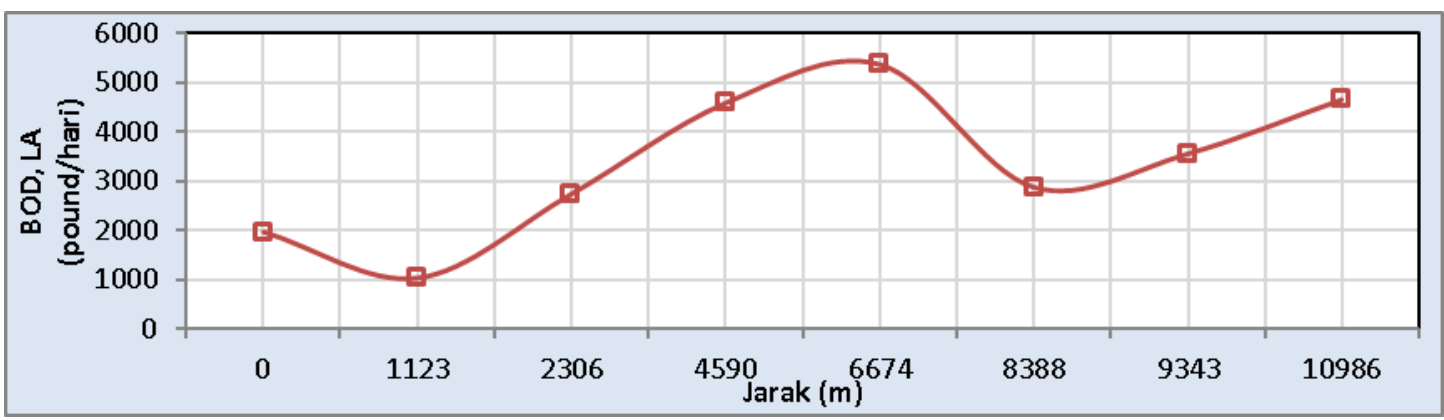

Gambar 6. Profil BOD ultimate di segmen Sungai Ancar 


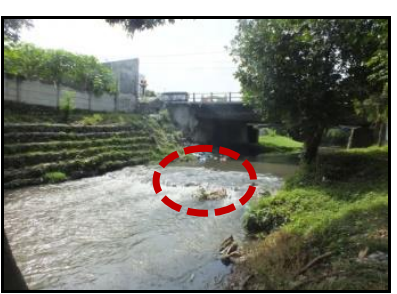

$\mathrm{T}-13$

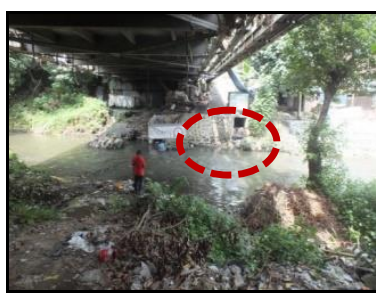

$\mathrm{T}-12$

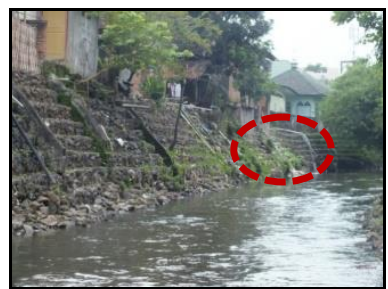

$\mathrm{T}-11$

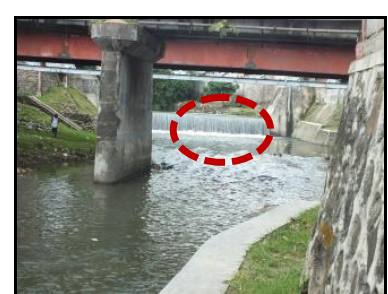

$\mathrm{T}-10$

Gambar 7. Lokasi pengambilan sampel air di segmen Sungai Ancar

Turbulensi akan meningkatkan laju reaerasi, sehingga memungkinkan terjadinya peningkatan oksigen terlarut dalam sungai ${ }^{(5,21,22)}$. Hal ini akan menghambat defisit oksigen terlarut (DO). Sebaliknya input air buangan rumah tangga dan atau industri, secara langsung maupun melalui saluran drainase, tentu akan meningkatkan konsentrasi polutan (dalam kasus ini adalah konsentrasi BOD) yang dapat meningkatkan konsumsi oksigen (defisit DO). Oleh karena itu, guna meningkatkan kapasitas daya tampung sungai, ada dua hal yang perlu dilakukan secara simultan, yaitu:

1) Mengendalikan pembuangan air limbah (baik domestik maupun industri) sehingga air sungai tetap memenuhi baku mutu sesuai dengan peruntukannya. Tabel 5 dan Tabel 6 menunjukkan nilai $\mathrm{DO}, \mathrm{BOD}$, dan $\mathrm{COD}$ hasil pengukuran dan Baku Mutu Air (BMA) sesuai dengan Peraturan Pemerintah No. 82 Tahun 2001.

2) Meningkatkan laju reaerasi sungai dengan intervensi teknologi (sederhana maupun high tech). Salah satu teknologi sederhana yang bisa dilakukan adalah meningkatkan riak aliran sungai dengan meletakkan bebatuan di dalamnya sehingga turbulensi air meniningkat atau pembangunan bendung yang sekaligus dapat berfungsi untuk irigasi.

Tabel 5. Nilai DO, BOD, dan COD hasil pengukuran

\begin{tabular}{c|c|c|c}
\hline \multirow{2}{*}{ Lokasi } & DO pengukuran & BOD $_{5}$ & COD \\
\cline { 2 - 4 } & (mg/L) & $\mathbf{~ m g / L}$ & $\mathbf{~} \mathbf{g} / \mathbf{L}$ \\
\hline $\mathrm{L}-5$ & 5.24 & 5.04 & 14.6 \\
\hline $\mathrm{L}-5-6$ & 5.44 & 5.24 & 12.7 \\
\hline $\mathrm{L}-6$ & 4.84 & 4.84 & 38.0 \\
\hline $\mathrm{L}-15$ & 3.43 & 4.84 & 11.7 \\
\hline $\mathrm{L}-14$ & 5.85 & 4.44 & 12.7 \\
\hline $\mathrm{L}-13$ & 5.64 & 5.16 & 15.6 \\
\hline $\mathrm{L}-12$ & 4.84 & 5.24 & 13.6 \\
\hline $\mathrm{L}-11$ & 5.24 & 4.84 & 15.6 \\
\hline $\mathrm{L}-10$ & 5.24 & 5.56 & 14.6 \\
\hline $\mathrm{L}-9$ & 4.64 & 5.24 & 13.6 \\
\hline $\mathrm{L}-8$ & 4.84 & 3.43 & 32.1 \\
\hline
\end{tabular}

Sumber: Hasil pengukuran Mei 2016

Tabel 6. BMA sesuai dengan kelas peruntukannya

\begin{tabular}{l|c|c|c|c|c}
\hline \multirow{2}{*}{ BMA } & \multirow{2}{*}{ Satuan } & \multicolumn{4}{c}{ Peruntukan Kelas } \\
\cline { 3 - 6 } & & $\mathbf{I}$ & II & III & IV \\
\hline BOD & $\mathbf{m g} / \mathbf{L}$ & 2 & 5 & 6 & 12 \\
\hline $\mathrm{COD}$ & $\mathbf{m g} / \mathbf{L}$ & 10 & 25 & 50 & 100 \\
\hline $\mathrm{DO}$ & $\mathbf{m g} / \mathbf{L}$ & 6 & 4 & 3 & 0 \\
\hline
\end{tabular}

Sumber: PP No. 82 Tahun 2001

\section{KESIMPULAN}

Berdasarkan profil DO defisit hasil perhitungan, terlihat bahwa Sungai Jangkok pada lokasi studi ini masih memiliki kemampuan untuk memulihkan polutan organik secara alamiah. Namun demikian DO defisit maksimum pada saat pengukuran telah mencapai 4164 
pound/hari atau setara dengan $1889 \mathrm{~kg} / \mathrm{hari}$. Penurunan tersebut dicapai hanya dalam waktu 0,57 menit sepanjang $474 \mathrm{~m}$. Oleh karena itu, meskipun daya pulihnya ada namun tingkat pencemaran yang terjadi perlu dikendalikan. Sedangkan hasil analisis di segmen Sungai Acar menunjukkan bahwa daya pulih Sungai Ancar relatif lebih rendah meskipun DO defisitnya lebih rendah dari Sungai Ancar, yaitu sebesar 2303 pound/hari atau $1044 \mathrm{~kg} / \mathrm{hari}$. Daya pulih di Sungai Ancar lebih disebabkan karena morfologi sungai yang dapat menimbulkan proses turbulensi karena adanya bendung maupun bebatuan. Guna mengendalikan daya pulih sungai Jangkok dan Sungai Ancar, perlu pengendalian air buangan (limbah) dan intervensi teknologi.

\section{PERSANTUNAN}

Penulis mengucapkan terima kasih kepada Lembaga IImu Pengetahuan Indonesia (LIPI) melalui Pusat Penelitian Metalurgiatas dukungan dana dalam pelaksanaan kegiatan penelitian ini.

\section{DAFTAR PUSTAKA}

1. Syahril, Nurdin, (2010), Kajian Manajemen Proyek Penyediaan Air Bersih Perkotaan Daerah Berbukit dengan Sumber Air Sungai, Jurnal Rekayasa Sriwijaya, 3 (9): 5-12.

2. Suhartanto, E., Priyantoro, D, dan Itratip, (2012), Studi Penilaian Kondisi DAS dan Implikasinya terhadap Fluktuasi Debit Sungai (Studi Kasus Pada Sub DAS Jangkok Pulau Lombok), Jurnal Teknik Pengairan , 3 (1): 1-5.

3. Kusnadi, Agus, (2015), Struktur Komunitas Annelida Sebagai Bioindikator Pencemaran Sungai Ancar Kota Mataram dan Upaya Pembuatan Poster untuk Pendidikan Masyarakat Tahun 2013. Prosiding Seminar Nasional Pendidikan Biologi 2015, 21 Maret 2015, Malang.

4. Murti, S.H., Wijdani, A.F., Jaya, A., Putri, A., Fahsya, A., Prabantoro, D., Dzimar A.R.P, dan Ratnasari, N., (2015), Estimasi Debit Puncak untuk Identifikasi Potensi Banjir pada DAS Jangkok Menggunakan Penginderaan Jauh dan SIG, Simposium Nasional Sains Geoinformasi IV, 25-26 November 2015, Yogyakarta.

5. Lee, C. C. dan Lin, Sun Dar, (2000), Handbook of Environmental Engineering Calculations, USA, McGraw-Hill.
6. Menezes, J.P.C., Bittencourt, R. P., Farias, M.dS., Bello, I. P., Oliveira, L. F.C, dan Fia, R., (2015), Deoxygenation Rate, Reaeration and Potential for SelfPurification of a Small Tropical Urban Stream, Ambiente\&Aqua - An Interdiciplinary Journal of Applied Science: 748-757.

7. Pelletier, G.J., Chapra, S.C., dan Tao, H., (2006), QUAL2Kw - A Framework for Modeling Water Quality in Streams and Rivers Using a Genetic Algorithm for Calibration, Environmental Modelling \& Software $21: 419-425$.

8. Mehrdadi, N., Ghobadi, M., Nasrabadi, T., dan Hoveidi, H., (2006), Evaluation of The Quality and Selft Purification Potential of Tajan River Using Qual2E Model. Iran J. Environ. Health. Sci. Eng., 3 (3):199-204.

9. Leandri, Marc, (2009), The Shadow Price of Assimilative Capacity in Optimal Flow Pollution Control. Ecological Economics, 68: 1020-1031.

10. Zhang, R., Qian, X., Yuan, X., Ye, R., Xia, B., dan Wang, Y., (2012), Simulation of Water Environmental Capacity and Pollution Load Reduction Using QUAL2K for Water Environmental Management. Int. J. Environ. Res. Public Health, 9: 45044521.

11. Kumarasamy, M.V., (2015), Deoxygenation and Reaeration Coupled hybrid Mixing cells Based Pollutant Transport Model to Assess water Quality Status of a River. Int. J. Environ. Res., 9 (1):341-350.

12. Yuceer, $M$ dan Coskun, M.A., (2016), Modeling Water Quality in River: A Case Study of Beylerderesi River in Turkey, Apllied Ecology and Environmental Research 14 (1): 383-395.

13. Sekhar M. Chandra dan Sreenivasulu, D., (2003), Modelling Nutrients Contributed by Overland Flow from the Khrishna River Basin. Diffuse Pollution Conference, 2003, Dublin.

14. Hema, S., dan Muthalagi, S., (2009), Mass Balance Approach for Assesment of Pollutant Loas in the Tamiraparani River, International Journal of ChemTech Research CODEN (USA), 1 (2): 385-389.

15. Skorzinki, E., Sharchom, M., dan Brauner, N., (2009), A Simulation Program for Modeling Pollutant Dispersion for Educational Applications, 19 ${ }^{\text {th }}$ European Symposium on Computer Aided Process 
Engineering (ESCAPE 19), J. Jezowki and J. Thullie (Editors).

16. Arwin dan Paramastuti, N., (2009), Dampak Degradasi Rezim Hidrologi di Kawasan Andalan Terhadap Kinerja PLTA, Infrastruktur Air Minum dan Sanitasi, Seminar Apresiasi Air dan Sanitasi di Kawasan Budidaya, Kerma ITB - Ditjen Cipta Karya PU.

17. Marganingrum, Dyah, (2013), Manajemen Sumber Daya Air Terpadu "Waduk Saguling" dalam Rangka Pengembangan Air Baku SPAM Regional KSN Cekungan Bandung, Disertasi, Program Studi Teknik Lingkungan-FTSL, ITB.

18. Rahayu S, Widodo $R H$, van Noordwijk M, Suryadi I dan Verbist B., (2009). Monitoring Air di Daerah Aliran Sungai. Bogor, Indonesia. World Agroforestry Centre, ICRAF - Southeast Asia Regional Office. $104 \mathrm{p}$.
19. Metcalf and Eddy, (2004). Wastewater Engineering, $4^{\text {th }}$ edition, Mc Graw Hill International Editions, New York.

20. Mahyudin, Soemarno, dan Tri Budi Prayogo, (2015). Analisis Kualitas Air Dan Strategi Pengendalian Pencemaran Air Sungai Metro di Kota Kepanjen Kabupaten Malang. J-PAL, 6 (2): 2338-1671.

21. Nurhasanah, Latifah K. Darusman, Surjono Hadi Sutjahjo dan Bibiana Widiati Lay, (2011). Efektifitas Pemberian Udara Berkecepatan Tinggi dalam Menurunkan Polutan Leachate TPA Sampah: Studi Kasus di TPA Sampah Galuga Kota Bogor, Forum Pascasarjana, 34 (1): 61 - 76

22. Rahmat R. A. Winardi D.N. dan Sudarno, (2015). Studi Kemampuan Selft Purification pada Sungai Progo Ditinjau dari Parameter Organik DO dan BOD, Jurnal Teknik Lingkungan-UNDIP, 4 (3): 1-15. 